\title{
Scanning Electron Microscope Analysis of Titanium Alloy Orthodontic Implants
}

\author{
ALEXANDRU VLASA ${ }^{1}$, CARMEN BIRIS ${ }^{1 *}$, LUMINITA LAZAR ${ }^{1}$, ANAMARIA BUD ${ }^{1}$, EUGEN BUD ${ }^{1}$, CRISTINA MOLNAR VARLAM ${ }^{1}$, \\ MARIUS MARIS ${ }^{2}$, MARIANA PACURAR ${ }^{1}$ \\ 'University of Medicine and Pharmacy Tirgu Mures, 50 Gheorghe Marinescu Str., 540139, Tirgu Mures, Romania \\ ${ }^{2}$ Titu Maiorescu University of Bucharest, Faculty of Dental Medicine, 67A Gh. Petrascu Str., 031593, Bucharest, Romania
}

\begin{abstract}
According to titanium's much higher hardness and strength compared with the bone, if correctly applied, mini-screws will suffer no damage. Reusing orthodontic mini-screws would reduce treatment cost and lead to more use of mini-screws and improvement of orthodontic treatments. In this study, scanning electron microscopy (SEM) was used to assess structural variations of retrieved orthodontic implants and to evaluate the mechanical properties that may adversely affect stability of orthodontic implants. For analisys 10 selfdrilling mini-implants retrieved after treatment, made from commercially pure $(C P)$ alpha-titanium from two brands Leone ${ }^{T M}$, Italy and ForestaDent ${ }^{T M}$, Germany were analised using SEM according to the degree of morphological deformation of the head, transmucosal neck, threaded body, and tip of the implant at up to 10,000 x light magnification. The mini-implants did not present any defects such as bubbles, imperfections or fissures in their internal microstructure. No significant marks resulting from the manufacturing process were observed. Surface irregularities in the threaded bodyand tip (fig. 5-7) were observed and significant tip deformation was evident in the majority (80\%) of retrieved mini-implants.
\end{abstract}

Keywords: scanning electron microscope, orthodontic screws, titanium alloy

Titanium and its alloys are widely used as orthopedic and dental implant materials because of their satisfactory mechanical properties, resistance to corrosion and biocompatibility [1, 2]. By biocompatibility we understand the property of a material to be compatible with living bodies, thus, to be accepted entirely by the body without generating side effects and without being chemically and mechanically deteriorated. [3]

The initial interaction between an implantand cells plays an important role in bone regeneration and osseointegration. Because pure titanium implants are bioinert to organisms, attempts have been devoted to modify their surface structures to improve the cellular response [4]. Micronanoscale topologies play an important role in implant osseointegration and determine the success of an implant. Nevertheless, though they positively promote osteoblast differentiation, microscale surfaces often inhibit osteoblast proliferation, resulting in a smaller accumulation of bone mass compared with that yielded by a smooth surface [510]. According to titanium's much higher hardness and strength compared with the bone, if correctly applied, miniscrews will suffer no damage [11]. Despite many attempts to modify the chemical features of Ti surfaces, the timedependent degradation of the chemical effects is substantial in that the strength of osseointegration is reduced in aged Ti surfaces compared with newly prepared Ti surfaces [12]. Miniscrew implants (MIs) have been recently widely utilized as anchorage reinforcement auxiliaries in orthodontics. Their clinical effectiveness lies in their ability to maintain close bone contact, thus resisting reactive orthodontic forces. MIs are fabricated from stainless steel, commercially pure titanium, or titanium alloy with a diameter of 1 to $2 \mathrm{~mm}$ and length of 8 to 20 $\mathrm{mm}$, and they are not osseointegrated [13]. Reusing orthodontic mini-screws would reduce treatment cost and lead to more use of mini-screws and improvement of orthodontic treatments. Reusing medical instruments has a long history and can only be performed when using or preparing the instrumentfor re-use doesn'tcause any harm to the instrument or alter its clinical features [14]. In this study, scanning electron microscopy (SEM) was used to assess structural variations of retrieved orthodontic implants and to evaluate the mechanical properties that may adversely affect stability of orthodontic implants. SEM can provide high resolution images (up to $5 \mathrm{~nm}$ ) evidencing general morphology, surface topography, pore geometry [15].

\section{Experimental part}

For analysis 10 self-drilling mini-implants retrieved after treatment, made from commercially pure (CP) alphatitanium from two brands Leone ${ }^{T M}$, Italy and ForestaDent ${ }^{T M}$, Germany, were stored in sterile saline solution for 5 days at room temperature. After storage scanning electron microscopy, LEO 1450VP + Inca 2000 EDS, LEO Electron Microscopy Ltd, Clifton Road, England was used to analyze structural variations according to the degree of morphological deformation of the head, transmucoseal neck, threaded body, and tip of the implantatup to $10.000 x$ light magnification.

\section{Titanium alloy analysis}

Energy-dispersive X-ray EDX spectroscopy, PANalytical B.V. Netherlands was used for examination of surface and determination of chemical structure of the mini-implants (fig.1, 2).

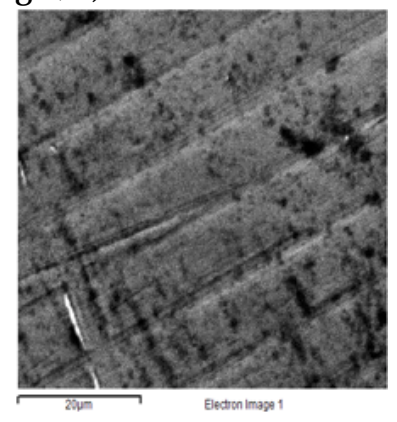

Fig.1. Examination of surface of mini-implants

\footnotetext{
* email: biriscarmen74@yahoo.com
} 


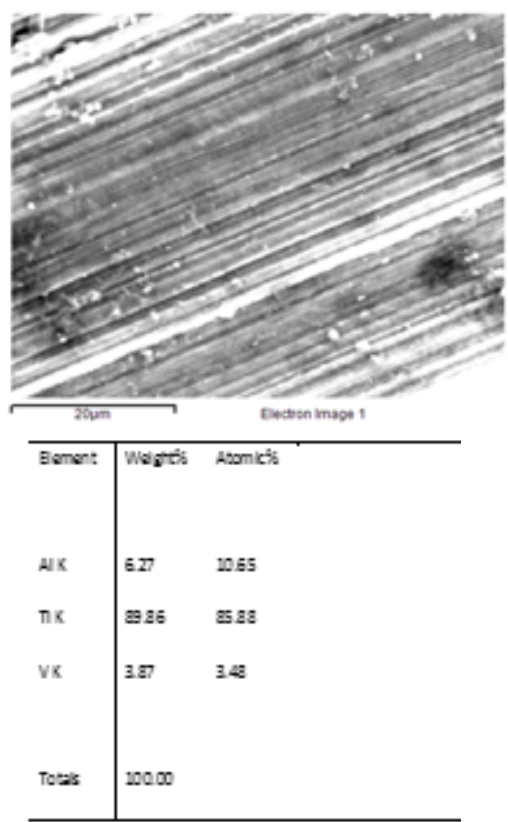

EDX is an analytical technique used for the elemental analysis or chemical characterization of a sample. It relies on an interaction of some source of $X$-ray excitation and $a$ sample. Energy-dispersive X-ray spectroscopy confirmed that the alloy is Ti6Al4V also known as commercially pure (CP) titanium alloy.

\section{Results and discussions}

The mini-implants did not present any defects such as bubbles, imperfections or fissures in their internal microstructure (fig.3). No significant marks resulting from the manufacturing process were observed (fig.4).

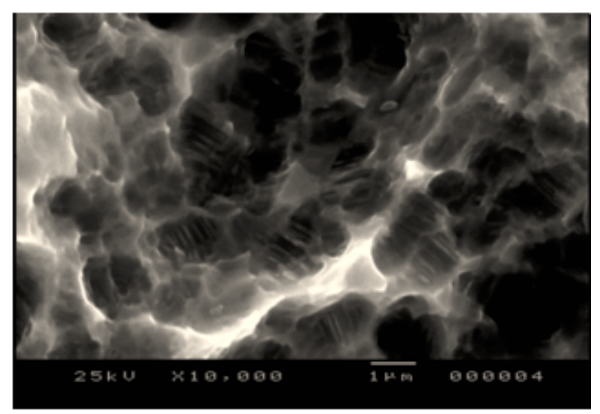

Fig.3. Internal microstructure of mini-implant (10.000X)

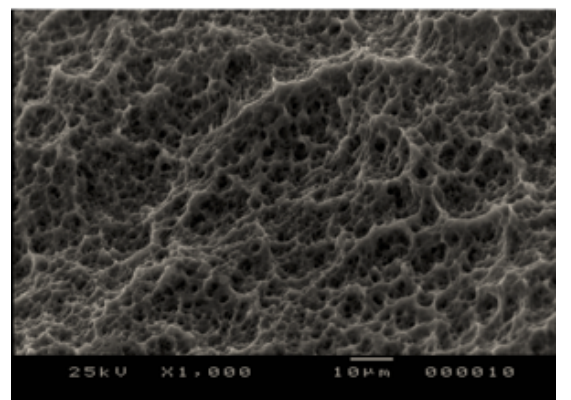

Fig. 4. Internal microstructure of mini-implant

(1.000X)

Surface irregularities in the threaded body and tip (fig.57) were observed and significant tip deformation was evident in the majority $(80 \%)$ of retrieved mini-implants. Deposited debris such as carbon, calcium, and phosphorus was observed on the retrieved mini-implants (fig.8). High bacterial loads were present in $100 \%$ of cases (fig.9).

Several recent studies tried to analyse methods for decontamination of retrieved mini-implants in order to reuse them. Stojicic et al. 2010 [16] reports that to omit organic remnants from mini-screws surfaces, application of phosphoric acid 37\% (10 min) followed by sodium hypochlorite $5-25 \%$ (30 $\mathrm{min}$ ) at room temperature is

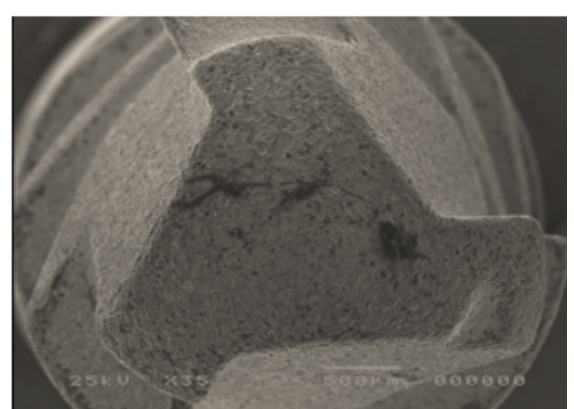

Fig.5. Surface irregularities in the tip (35X)

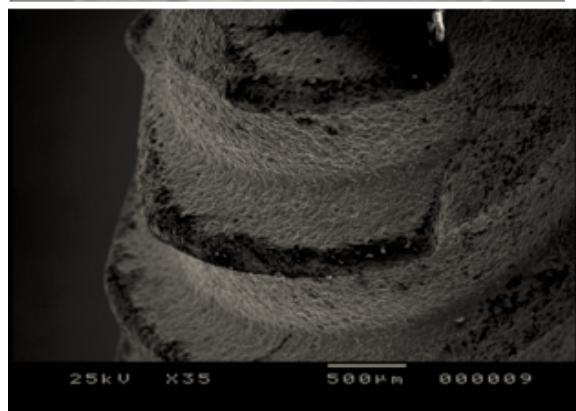

Fig.6. Surface irregularities in the threaded body

(35X)

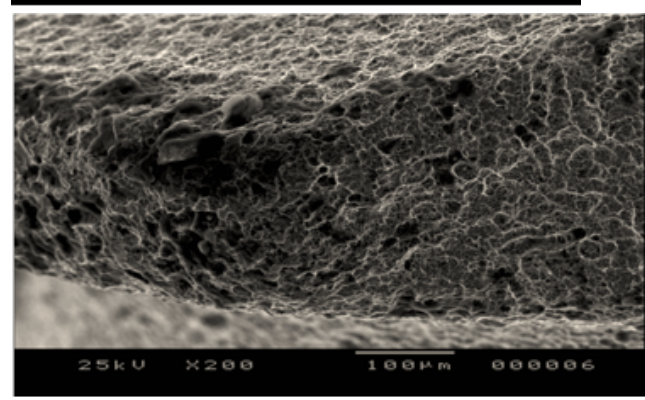

Fig.7. Surface irregularities (200X)

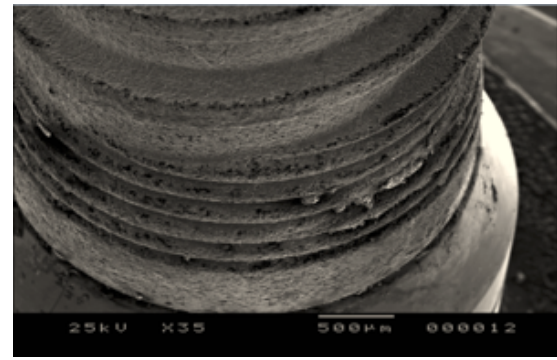

Fig.8. Deposited debris on miniimplant surface (35X)

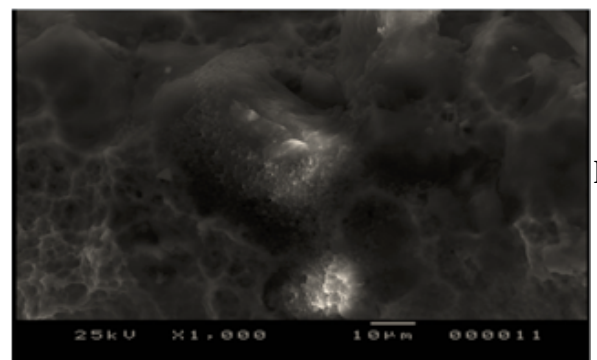

Fig. 9. High bacterial loads (1.000X)

recommended. El-Wassefya et al. 2015 [17] states that whatever the method of sterilization is used, the microimplant surface cannot be considered the same as the original in terms of surface morphologic properties, ion release and histologic cell response. The autoclavesterilized micro-implants showed better histologic results than the micro-implants sterilized by gamma rays or ultraviolet rays. Mini-implants retrieved after primary insertion may exhibit decreased cutting ability due to deformation of the tip structure, as well as surface contamination.

\section{Conclusions}

We conclude that differences in mini-implant structure and the presence of surface irregularities may influence the effectiveness of orthodontic anchorage and we do not recommend reusing of orthodontic implants. 


\section{References}

1.SATOMI K, ALAGAWA Y, NIKAI H, TSURU H. Bone-implant interface structures after nontapping and tapping insertion of screw-type titanium alloy endosseous implants. J Prosthet Dent. 1988;59:339342.

2.SCHMIDT C, KASPAR D, SARKAR MR, CLAES LE, IGNATIUS AA. A scanning electron microscopy study of human osteoblast morphology on five orthopedic metals. J Biomed Mater Res. 2002;63:252-261 3.COMANEANU, R.M., HANCU, V., BARBU, H.M., COMAN, C, COTRUT, CM, TARCOLEA, M, HOLICOV, A.M, ORMENISAN, A., Comparative assessment of biocompatibility of $\mathrm{NiCr}$ and $\mathrm{CoCr}$ alloys used in metalfused-to-ceramic technology, Rev. Chim. (Bucharest), 66, no. 3, 2015, p. 312

4.LU XIA, BO FENG, PEIZHI WANG, SIYANG DING, ZHIYUAN LIU, JIE ZHOU, RONG YU In vitro and in vivo studies of surface-structured implants for bone formation International journal of nanomedicine 10.09.2012

5.YANG GL, HE FM, YANG XF, WANG XX, ZHAO SF. Bone responses to titanium implants surface-roughened by sandblasted and double etched treatments in a rabbit model. Oral Surg Oral Med Oral Pathol Oral Radiol Endod. 2008; 106(4):516-524.

6.COCHRAN DL, BUSER D, TEN BRUGGENKATE CM, et al. The use of reduced healing times on ITI implants with a sandblasted and acidetched (SLA) surface: early results from clinical trials on ITI SLA implants. Clin Oral Implants Res. 2002;13(2):144-153.

7.KIM MJ , KIM CW, LIM YJ , HEO SJ . Microrough titanium surface affects biologic response in MG63 osteoblast-like cells. J Biomed Mater Res A.2006; 79(4):1023-1032.

8.LOHMANN CH, BONEWALD LF, SISK MA, et al. Maturation state determines the response of osteogenic cells to surface roughness and 1,25-dihydroxyvitamin D3. J Bone Miner Res. 2000;15(6):11691180.
9.BOYAN BD, LOSSDÖRFER S, WANG L, et al. Osteoblasts generate an osteogenic microenvironment when grown on surfaces with rough microtopographies. Eur Cell Mater. 2003;6:22-27.

10.SCHWARTZ Z, OLIVARES-NAVARRETE R, WIELAND M, COCHRAN $\mathrm{DL}, \mathrm{BOYAN} B \mathrm{BD}$. Mechanisms regulating increased production of osteoprotegerin by osteoblasts cultured on microstructured titanium surfaces. Biomaterials. 2009;30(20):3390-3396

11.SAEED NOOROLLAHIAN, SHIVA ALAVI, ELAHE RAFIEI The effect of multiple processing and re-use on orthodontic mini-screw torque values, Dent Res J (Isfahan). 2015 May-J un; 12(3): 243-247

12.LEE JH, OGAWA T (2012) The biological aging of titanium implants. Implant Dent 21(5): 415-421.

13.SAEED NOOROLLAHIAN, SHIVA ALAVI AND MOHAMMAD MONIRIFARD A processing method for orthodontic mini-screws reuse, Dent Res J (Isfahan). 2012 J ul-Aug; 9(4): 447-451

14.PAPADOPOULOS MA, TARAW NEH F (2007). The use of miniscrew implants for temporary skeletal anchorage in orthodontics: a comprehensive review. Oral Surg Oral Med Oral Pathol Oral Radiol Endod 103:e6-e15

15.RUSU, LC, ARDELEAN, L, NEGRUTIU, M.L., DRAGOMIRESCU, A.O., ALBU, M.G., GHICA., M.V., TOPALA,. FI., PODOLEANU, A., SINESCU, C., SEM for the General Structural Features Assesing of the Synthetic Polymer Scaffolds, Rev. Chim. (Bucharest), 62, no. 8, 2011, p. 841 16.STOJ ICIC S, ZIVKOVIC S, QIAN W, ZHANG H, HAAPASALO M. Tissue dissolution by sodium hypochlorite: Effect of concentration, temperature, agitation, and surfactant. J Endod. 2010;36:1558-62 17.NOHA EL-WASSEFYA; ABEER EL-FALLALB; MAHASEN TAHA, Effect of different sterilization modes on the surface morphology, ion release, and bone reaction of retrieved micro-implants The Angle Orthodontist: January 2015, Vol. 85, No. 1, pp. 39-47

$\overline{\text { Manuscript received: } 24.12 .2016}$ 